\title{
Five Policy Options in Face of Euro Crisis
}

\section{Ping-Yen Lai ${ }^{1 *}$ and Jimmy Teng ${ }^{2}$}

${ }^{1}$ Department of Translation and Interpretation, National Changhua University of Education, Changhua, Taiwan

${ }^{2}$ Department of Economics, University of Nottingham, Malaysia Campus, Malaysia

\section{Introduction}

The current problem of euro zone can be characterized as the internal distribution of saving and investment. The euro zone as a whole has sufficient saving to finance the investment. Although there is an excess of saving in northern Europe, savers in the north are unwilling to finance southern Europe due to the current crisis [1]. Although German has a current-account surplus, which is more than enough to cover the current account deficit of the rest of eurozone countries, there is no sign of convergence across regions [2].

Typically in a debt crisis, there are three options: bailouts, debt discounts, and debt forgiveness. The latter two are also referred as debt restructuring. For example, during the Latin America debt crisis in the 80s, the bailout option was adopted first, and followed by discount and forgiveness due to its ineffectiveness. The eurozone crisis is no exception, except that it also involves a common currency and members. Thus, whether euro should be abandoned and whether some or all of its members should exit the eurozone become a heated issue. In face of euro crisis, internal devaluation and bailout has been actively pursued and much criticized. Such criticisms led to four other options advocated by major economists: restructuring of debts, devaluation of euro, default and partial exit of peripheral countries, and finally, a complete elimination of euro. If things cannot change for the better, worries would be vindicated and some version of other options could be introduced to complement the current policy.

\section{The Five Policy Options}

Internal and external devaluation are options for restoring competitiveness, while others are options for easing up the hardship on economies or stabilizing the impact on financial sectors.

\section{Internal devaluation combined with bailouts}

Internal devaluation, i.e. the lowering of costs and wages, by itself could make things even worse as countries go through its vicious cycle: debt load is heavier in terms of real value once wages and costs are lowered, and as debt becomes heavier, spending has to be decreased or taxes have to be increased in order to service the heavier debt, thus creating the need for more cut in wages and costs [3]. As internal devaluation is recessionary, there must be something that goes with it to ease up its hardship, especially when the required adjustment is huge and the recessionary period could be long.

In order to regain competitiveness in the euro zone, the magnitude for price devaluation is huge. According to a recent study, the price level must drop 20\% for France, $10-15 \%$ for Italy, 20\% for Spain, and 30 to $35 \%$ for Greece and Portugal [4]. Also, the process of returning to competitiveness could be long as it took Germany ten years to do it that way. What this means for countries such as Spain, with unemployment rate at $25 \%$ and youth employment rate at $50 \%$, could be a waste of a whole generation [5].
In addition, the cost will likely be trillion of dollars as sufficient official financing will have to be provided to allow investors to exit. Investors will keep pulling out of the peripheral economies due to their shaky fundamentals, and official finance will be required to restore the resulting imbalances. Such form of capital flight could last for years until confidence is restored in these economies. So far, such official finance has come from fiscal authorities such as the European Financial Stability Facility, as well as the International Monetary Fund and increasingly from the European Central Bank. Currently, Germany and ECB are relying on such large scale injection of liquidity to buy time until growth and competitiveness are restored [6]. Overall, the bailout money from these institutions, together with more EU influence on fiscal policies across the region, suggests a fiscal union that is stronger than ever [7].

Capital flight in EU peripheral is occurring and accelerating as bailout money is being provided. Private capital was effectively driven away by the cheaper official credits ${ }^{1}$. The replacing of private capital by public money would have its adverse effect on restoring the balance of payment imbalance, the very goal that internal devaluation is trying to achieve [8].

In sum, the bailout option pursued by EU involved two key elements, first, the socializing of public debt, which has been actively pursued through EFSF and could be further expanded under the discussions of Eurobonds, and second, the socialization of bank debt. The so called banking union belongs to the latter category [9]. However, the magnitude of capital involved under the second category is much larger. For example, Spain, its public debt to GDP ratio is $69 \%$, while its banking debt totals at $305 \%$ of $\mathrm{GDP}^{2}$.

\section{Restructuring of debts}

Bank debts have to be converted into equity or written off. However, writing down debts, especially foreign debts, could destabilize other countries and banks' balance sheet will need to be recapitalized. Debtequity swaps could serve as a way to recapitalize the banks, mush as what has been done by US during the mortgage crisis. Restructuring of debts was advocated by UC Berkeley economist Barry Eichengreen to combine with internal devaluation as a way to ease up its hardships on the economies ${ }^{3}$.

\section{Devaluation of the euro}

This is not a likely scenario as the German economy is performing

*Corresponding author: Ping-Yen Lai, Department of Translation and Interpretation, National Changhua University of Education, Changhua, Taiwan, E-mail: pingyenl@yahoo.com.tw

Received January 13, 2013; Accepted January 15, 2013; Published January 23, 2013

Citation: Lai PY, Teng J (2013) Five Policy Options in Face of Euro Crisis. J Glob Econ 1:e101. doi:10.4172/2375-4389.1000e101

Copyright: (c) 2013 Lai PY, et al. This is an open-access article distributed under the terms of the Creative Commons Attribution License, which permits unrestricted use, distribution, and reproduction in any medium, provided the original author and source are credited. 
quite well [10] and the style of ECB has long been shaped by tight, rather than loose monetary policy. A change of face could endanger the credibility that has long being established by ECB and its earlier predecessor, the Bundesbank. Such idea has so far been rejected by EU. Devaluation as a policy proposal has been endorsed by Harvard economist Martin Feldstein. He suggested that devaluation in the range of $20 \%$ to $25 \%$, which is close to the range of internal devaluation mentioned earlier, could benefit the current account deficit faced by most eurozone countries ${ }^{4}$.

\section{Default, exit and external devaluation of some peripheral economies}

Peripheral countries such as Greece and Portugal could default and exit the euro zone. By returning to national currency and devaluate it, EU's peripheral economies could regain competitiveness and growth within a short time. This could create capital loss for foreign financial institutions as debt denominated in foreign currency would surge relative to national currency and debt countries would have difficulties in servicing these debts. Recapitalization of banks, both in core and in peripheral countries, would be required to prevent chaos in financial markets. The exit of peripheral countries, when combined with debt restructuring and capital injection, has been endorsed by NYU economist Nouriel Roubini. Such exit scenario has been predicted by economists such as Martin Feldstein and Kenneth Rogoff and one would naturally feel that it is almost an implied consensus among major economists.

\section{The complete elimination of euro}

Euro did not qualify as an optimum currency area as several key ingredients are missing: labor mobility, fiscal transfer, lender of last resort $^{5}$. The complete elimination of euro could serve as a way to eliminate such an inherent wrong design. This policy option is favored by Harvard economist Robert Barro. He advocated an exit strategy that Germany issued a parallel new D-Mark, pegged at 1.0 to the Euro and the Germany government provides guarantees for its government debt holders over a two-year period. And such path should also be followed by other countries over a two-year period. A clear benefit of such regime is that countries would clearly be able to service their debt, which would now be denominated in their local currencies ${ }^{6}$. For countries such as Italy, such system would be more credible as it no longer has to depend on outside financing to service its debt ${ }^{7}$.

\section{Conclusions}

Among these suggested policy options, debt restructuring is a key ingredient that should go either with internal or external devaluation. In light of the dire consequences under internal devaluation and constant bailout, the exit of EU peripheral economies would be a lesser evil and it is consensual among major economists. The timing of such exit is important because it involves whether such impact can be contained, i.e. whether a firewall is well established between major economies such as Spain and Italy and peripheral economies. Judging from previous history of financial crisis, such as Latin American debt crisis and US Saving and Loan crisis, it appears that bailout is almost always phrase one, and things never quite end there.

\section{References}

1. Daniel Gros (2012) The Decline and Fall of the Euro. In: Economic Policy, 2

2. Martin Feldstein (2012) An Optimistic Case for the Euro. Project Syndicate.

3. Barry Eichengreen (2010) Europe's Inevitable Haircut. Project Syndicate.

4. Hans-Werner Sinn (2012) A Crisis in Full Flight. Project Syndicate.

5. Kenneth Rogoff (2012) A Centerless Euro Cannot Hold. Project Syndicate.

6. Nouriel Roubini (2012) Early Retirement for the Euro Zone. Project Syndicate.

7. Robert Barro (2012) An Exit Strategy from the Euro. The Wall Street Journal.

8. Hans-Werner Sinn (2011) The Trouble with Euro Bonds. Project Syndicate.

9. Hans-Werner Sinn (2012) The European Banking Union? Project Syndicate

10. Nouriel Roubini (2012) Greece Must Exit. Project Syndicate.

\footnotetext{
${ }^{4}$ See An Optimistic Case for the Euro.

${ }^{5}$ See discussions in A Centerless Euro Cannot Hold by Kenneth Rogoff.

${ }^{6}$ See An Exit Strategy From the Euro by Robert Barro.

${ }^{7}$ See An Exit Strategy From the Euro by Robert Barro.
} 